\title{
Yerli ve Yabancı Turist Deneyimi: Gelibolu Yarımadası Tarihi Milli Parkı Milliyet Temelinde Bir Analiz*
}

\author{
Domestic and Foreign Tourist Experience: The Case of Gallipoli Nationality Based Analysis \\ Neslihan CAVLAK**, Ruziye COP*** \\ **Öğr. Gör. Dr., Tekirdağ Namık Kemal Üniversitesi Malkara MYO Turizm ve Otel İşletmeciliği Bölümü, 59300 Malkara, Tekirdağ. \\ E-posta: neslihancavlak@hotmail.com \\ ORCID: 0000-0002-6712-971 \\ ***Prof. Dr., Bolu Abant İzzet Baysal Üniversitesi iỉBF İşletme ABD Gölköy Yerleşkesi, 14030 Merkez, Bolu. \\ E-posta: ruziyecop@hotmail.com \\ ORCID: 0000-0002-2053-2157
}

\section{MAKALE BILGILERI \\ Makale işlem bilgileri: \\ Gönderilme tarihi: 16 Eylül 2018 \\ Düzeltme: 27 Şubat 2019 \\ Düzeltme: 6 Nisan 2019 \\ Kabul: 22 Nisan 2019}

Anahtar sözcükler: Müşteri deneyimi, Gelibolu Yarımadası Tarihi Milli Parkl, Rasyonel turist deneyimi,

Duygusal turist deneyimi.

\section{ARTICLE INFO}

Article history:

Submitted: 16 September 2018

Resubmitted: 27 February 2019

Resubmitted: 6 April 2019

Accepted: 22 April 2019

Key words: Customer experience, Gallipoli, Rational tourist experience, Emotional tourist experience.

\begin{abstract}
öz
Bu çalışmanın amacı, aynı destinasyonu aynı zaman diliminde ziyaret eden ve benzer deneyimler yaşayan turistlerin destinasyonda yaşadıkları deneyimin değerlendirmesini yapmak ve yerli ve yabancı turist gruplarının yașadıkları deneyimler arasında bir farklılık olup olmadığını ortaya koymaktır. Araștırma, Canakkale - Gelibolu Yarımadası Tarihi Milli Parkı'nı ziyaret eden ve burada en az bir gece konaklama yapan yerli ve yabancı turistler üzerinde yapılmıştır. Araştırmanın örneklemini 409 yerli turist ve 243 yabancı turist olmak üzere toplam 652 katılımcı olușturmaktadır. Araștırma verileri yüz yüze anket tekniği kullanılarak toplanmıştır. Araştırmanın sonuçları, aynı zaman diliminde Gelibolu Yarımadası Tarihi Milli Parkı'nı ziyaret eden yerli ve yabancı turistlerin yaşadıkları deneyimler arasında bazı farklılıklar olduğunu ortaya koymaktadır. Yerli turistlerin destinasyonda yabancı turistlere göre daha duygusal bir deneyim yaşadıkları görülmektedir.
\end{abstract}

\begin{abstract}
The aim of this study is to evaluate the experience of the tourists who have visited the same destinations in the same time period and have similar experiences, and to find out whether there is any difference between the experiences of the groups of domestic and foreign tourists. The research was carried out on the local and foreign tourists visiting the Gallipoli and stayed there at least one night. The sample of the study consisted of 652 participants, 409 of which were domestic tourists and 243 foreign tourists. The data were collected by face to face survey technique. The results of the study show that there are differences between the experiences of local and foreign tourists who visited the Gallipoli in the same time period. It is observed that local tourists have experienced more emotional experience than foreign tourists in the destination.
\end{abstract}

\section{GíRiş}

Turizm sektörü bir deneyim sektörüdür. Deneyimler; mallardan ve hizmetlerden farklı özelliklere sahip ekonomik sunulardır. Başarılı deneyimler, turistin zaman içinde benzersiz, unutul-

\footnotetext{
* Bu çalışma, Abant İzzet Baysal Üniversitesi, Sosyal Bilimler Enstitüsü İşletme Dalında, Prof. Dr. Ruziye Cop danışmanlı̆̆ında yazılan, "Müş̧eri Deneyiminin Destinasyon Imajı Üzerindeki Etkileri: Türk ve Anzak Turistler Üzerine Karşılaştırmalı Bir Araştırma" başlıklı doktora tezinden üretilmiştir.
}

maz ve sürdürülebilir bulduğu, tekrar etmesini istediği ve ağıdan ağıa pazarlama yoluyla paylaştığı durumlardır (Pine ve Gilmore 1999: 3). Turizm sektörünün en önemli unsurlarından olan konaklama, ulaşım, perakendecilik, destinasyon yönetimi, yiyecek içecek ve seyahat hizmetleri sunan işletmeler turistlere farklı farklı deneyimler yaşatmaktadırlar. İşletmeler genellikle müşterilerine alışılmışın dışında, her gün yaşadıkları rutinden farklı ve rakiplerinin öngöremediği deneyimler yaşatmayı isteyebilmektedir. 
Turistler bir destinasyonu deneyim ile ilgili istek ve gereksinimlerini karşılamak amacıyla ziyaret etmektedir. Turizm deneyimi bir destinasyon için küresel bir tüketim deneyimi olarak görülebilmektedir. Destinasyonlar, turizm sisteminin çekirdeği (Fyall ve Leask 2006: 50), konaklama, ulaşım, yiyecek, hediyelik eşya ve boş zaman etkinlikleri ile bütüncül bir ürünü ifade etmektedir. Bu anlamda, destinasyonlar turistler tarafından bir bütün olarak algılanmaktadırlar. Turistin algıladığı deneyim, destinasyonun tüm unsurlarının kendisine bir bütün olarak yaşattı$\breve{g} 1$ deneyimdir (Agapito, Valle ve Mendes 2014: 225). Turizm etkinlikleri, her ziyaretçi için kişisel bir deneyim sunaktadır. Turizm pazarlamacıları, turistlere yarar sağlayacak, turistleri, turizm endüstrisini ve yerel halkı da içerisine alan pozitif ve unutulmaz deneyimler geliştirmek amaciyla uygun bir çevre yaratmaya çalışmalıdır. Bir destinasyona ait, pazarlama ve yönetim stratejilerinin başarılı olabilmesi için turistleri etkileyebilecek pozitif, eşsiz ve kaliteli turist deneyimlerinin yaratılması büyük önem taşımaktadır. Çünkü destinasyonların sürdürülebilirliği ve rekabet edilebilirliği ancak bu şekilde sağlanabilmektedir (Carbone ve Haeckel 1994; Kim ve Moon 2009; Tung ve Ritchie 2011; Kim, Hallab ve Kim 2012).

Türkiye gibi dinamik, oldukça genç bir nüfusa sahip, eşsiz tarihi, kültürel ve doğal güzellikleri olan bir ülkede turizm faaliyetleri büyük önem taşımaktadır. Rekabetin oldukça yoğun oldu$\breve{g u}$ turizm endüstrisinde müşterilerin istek ve beklentilerinin tam olarak anlaşılması oldukça önemlidir. Ancak daha çok soyut bir yapıya sahip turizm ürünleri, turistler tarafından farklı şekillerde algilanabilmektedir. Bu nedenle, turistlerin gittikleri destinasyonda yaşadıkları deneyimi nasıl algıladıklarının bilinmesi büyük önem taşımaktadır. Bu çalışmada, yerli ve yabancı turistlerin destinasyonda yaşadıkları deneyimlerin karşılaştırmalı olarak ortaya koyulması amaçlanmaktadır. Bu araştırmadan elde edilen sonuçların alanyazına katkı sağlayacağı düşünülmektedir. Araştırmada aynı destinasyonu aynı zaman diliminde ziyaret eden ve benzer deneyimler yaşayan turistlerin destinasyonda yaşadıkları deneyimin değerlendirmesinin yapılması ve yerli ve yabancı turist gruplarının yaşadıkları deneyim- ler karşılaştırmalı olarak ortaya koyulmaktadır. Ayrıca bu çalışmanın bulgularından yola çıkan destinasyon yöneticileri ve pazarlamacıları, destinasyona gelen turistlere daha yüksek kalitede bir deneyim paketi sağlamak için ciddi ve entegre bir yaklaşım benimseyebilecekleridir.

\section{ALANYAZIN TARAMASI}

Çalışmanın bu bölümünde, rasyonel ve duygusal olmak üzere iki boyuttan oluşan müşteri deneyimi konusunda yapılan alanyazın taraması bulunmaktadır.

\section{Müşteri Deneyimi}

Müşteri deneyimi kavramı, tüketici davranışı alanyazınına ilk olarak 1980'lerin ortalarında yaygın bir şekilde girmiştir. Bu yaklaşım, müşterileri, sadece rasyonel karar vericiler olarak kabul eden akıma karşı yeni bir deneyimsel yaklaşım sunarak tüketici davranışı alanyazınına orijinal bir bakış getirmeyi amaçlamaktadır (Holbrook ve Hirschman 1982: 132). Müşteri deneyimi yaklaşımı; müşterilerin düşünme ve yapma yanında hisseden varlıklar da olduklarını savunarak, duyguların davranışlar üzerindeki rolünün göz önüne alınması gerekliliğini vurgulamaktadir (Addis ve Holbrook 2001: 50). Schmitt (1999) deneyimsel pazarlamacılarına göre müşterilerin, rasyonel oldukları kadar duygusal varlıklar olduklarını savunmaktadır. Müşteriler genellikle rasyonel kararlar almaya çalışırlarken diğer taraftan da duygulariyla da hareket etmektedirler. Bunun en önemli nedeni ise tüketim deneyiminin genellikle hayal gücü (fanteziler), hisler ve eğlence arama peşinde koşmasıdır (Schmitt 1999: 58).

Turist deneyimi konusunda daha önce yapılmış olan çalışmalarda genellikle turist deneyiminin nasıl oluştuğu, turist deneyimini etkileyen unsurların neler olduğu ve bu unsurların turistin davranışı üzerindeki etkilerinin neler olduğu sorularına cevap arandığı görülmektedir. Son ylllarda turist deneyimi konusunda yapılan çalışmalarda genellikle ampirik, nitel ve nicel yöntemler kullanılmaktadır. Araştırmacıların (Bitner 1992; Oh, Fiore ve Jeoung 2007; Kim ve Moon 2009; Hosany ve Witham 2010; Walls vd. 
2011) daha çok turizm işletmelerinin (otel, restoran, seyahat acentası gibi) müşterilere yaşattığ1 deneyim konusunda çalıştıkları görülmektedir. Yapılan çalışmaların bazılarında (Hirschman ve Holbrook 1982; Oh vd. 2007; Walls vd. 2011) tüketim deneyiminin duyguların ve düşüncelerin bir bileşimi olduğu ortaya koyulurken, bazılarında (Schmitt 1999; Berry vd. 2002, Ritchie ve Hudson 2009) duygusal unsurların satın alma sürecinde daha etkin olduğu ortaya koyulmaktadır. Turizm işletmeleri (otel, kafe, restoran gibi) sahip oldukları fiziksel unsurları, süreçleri, uygulamaları, çalışanları ve diğer müşterileri ile tüketicilere bir deneyim yaşatmaktadır. Aynı şekilde, destinasyonlar da kendi içlerinde barındırdıkları, müşterilere bütünleşik bir deneyim sunan birçok turistik mal ve hizmetin birleşmesinden meydana gelmektedir. Bu mal ve hizmetler, müşterilere rasyonel ve duygusal deneyimler yaşatmayı amaçlamaktadır. Bu çalışmada yaşanan bu deneyimler, bir turizm destinasyonu ile ilişkilendirilerek turizm alınyazına katkıda bulunması düşünülmektedir.

Günümüz müşterisi, rasyonellik ile duygusallık arasında salınan bir varlık olarak tanımlanabilmektedir. Turistler, bir taraftan maliyet bilincine sahip rasyonel boyutta hareket ederken, diğer taraftan da huzur arayan duygusal boyuta geçebilmektedir (Gronau 2017: 266). Bu nedenle, çalışmada müşteri deneyimi rasyonel ve duygusal deneyim olmak üzere iki boyutta ele alınmaktadır. Çünkü iyi bir deneyim tasarımının ancak, müşterilerin istek ve beklentileri doğrultusunda, işletmenin sunacağı hizmetlerdeki rasyonel ve duygusal unsurların bir arada planlaması yoluyla müşteriler ile olumlu bir bağ kurularak oluşabileceği tezi ortaya koyulmak istenmektedir. Son yıllarda müşteri deneyimi her ne kadar popüler bir konu olsa da turizm alanında yapılan çalışmalar oldukça kısıtlıdır. Bu çalışmanın turizm alanyazınına bu anlamda da katkıda bulunacağ 1 düşünülmektedir.

\section{Rasyonel Müşteri Deneyimi}

Seyahatle ilgili kararlar, turizm hizmetlerinin doğası gereği yüksek riskler içermekte ve bu nedenle kapsamlı bilgi arama stratejileri gibi risk azalt- ma stratejileri gerektirmektedir. Turistler alternatif destinasyon seçimlerinde rasyonel davranış sergilemekte ve en iyi hizmeti sunan destinasyonu seçmektedirler (Sirakaya ve Woodside 2005: $820)$. Buna göre, turistler gidecekleri destinasyonlar hakkında araştırma yapmakta, uzmanlardan bilgi almakta ve fiyat karşılaştırmaları yaparak en az maliyet ile en çok yararı sağlayabilecekleri destinasyonlara yönelmektedirler. Turistlerin destinasyonlarda yaşadıkları rasyonel deneyim seyahat öncesi hazırlık deneyimi ile başlamaktadır. Seyahatin planlanma aşamasında turist, nereye gideceği, orada ne yapacağı, ne kadar kalacağı, ulaşım, konaklama ve seyahat rotası gibi unsurlara odaklanmaktadır. Seyahat planlaması genel olarak, amaçlara ulaşılmak için önceden yapilan birçok eylemden oluşan bir hareket planıdır ve bu aşamada birden fazla amaç birbirine bağlanmış olabilmektedir. Seyahat planlaması aşamasında daha az deneyimli turistler seyahatleri hakkında daha geniş ve kapsamlı bir araştırma yapmakta ve bilgi arama konusunda büyük çaba ve zaman harcamaktadırlar. Geniş kapsamlı yapilan planlama, yapilacak seyahat konusundaki belirsizliğin seviyesini ve algılanan riski azaltabilmekte (Becken ve Wilson 2007: 47) ve seyahatin kalitesini arttırabilmektedir (Bieger ve Laesser 2004: 357). Rasyonel müşteri deneyimi sonucunda oluşan memnuniyet, turistlerin destinasyona ait unsurlardan edindikleri olumlu bir alg1 ya da duygu olup, bu tecrübelerden elde edilen tatminin derecesini ifade etmektedir. Turistin memnuniyetinin destinasyon yöneticileri açısından öneminin büyük olmasının sebebi ise turist memnuniyetinin destinasyon seçimini (Kozak ve Rimmington 2000: 260; Tian-Cole ve Cromption 2003: 65) ve gelecekteki turist davranışını etkilemesidir (Tian-Cole ve Cromption 2003: 65; Yoon ve Uysal 2005).

\section{Duygusal Müşteri Deneyimi}

Her geçen gün artan rekabetle yüz yüze olan destinasyon pazarlamacıları açısından turizm sunumlarının sembolik değerlerinin ve deneyimsel kalitelerinin anlaşılması büyük önem taşımaktadır (Gretzel, Fesenmaier, Formica ve O'Leary 2006: 119). Çünkü deneyimsel pazarlamacılar 
müşterilerini keyifli deneyimler yaşamak isteyen duygusal varlıklar olarak görmektedirler (Williams 2006: 485). Destinasyon pazarlamacılar1nın, anlamlı bir müşteri deneyimi sunmanın en önemli unsurlarını anlamaya çalışmaları büyük önem taşımaktadır.

Tatil yapanlar için, kişisel bir değer taşıyan turizm deneyimine tatmin edici ve haz verici duygular eşlik etmektedir (Hosany ve Gilbert 2010: 513). Turistlerin destinasyonlarda yaşadıkları duygusal deneyim üç çeşitten oluşabilmektedir. Bunlar; eğlence, kaçış ve estetik deneyimleridir. Eğlence deneyimi; insanların tatile çıkma kararı almalarında oldukça etkili bir güdüdür (Yüksel ve Yüksel 2001: 333). Loi (2008: 165) eğlencenin, turistlerin destinasyon seçimlerinde en önem verdikleri unsur olduğunu belirtmiştir. Estetik deneyimi, özellikle de turistlerin seyahat ettikleri destinasyonu değerlendirmeleri ve tatil deneyimleri açısından önemli bir belirleyicidir (Oh, Fiore ve Jeoung 2007: 119). Turizm pazarlamas1 alanyazınında, turistlerin seyahatlerinde yaşadıkları estetik unsurunun turistin deneyimini ve memnuniyetini olumlu yönde etkilediği, destinasyona olan sadakatine (Lee, Jeon ve Kim 2011: 1124) ve tekrar ziyaret etme niyetine olumlu yönde katkıda bulunduğu kabul edilmektedir. Soyut ve somut unsurları içerisinde barındıran çevrenin, tüketim deneyimine katkıda bulunmasından dolayı tüketici davranışını etkilediği bilinmektedir (Bitner 1992; Hosany ve Witham 2010; Çetin 2012). Bu bakış açısı ürünlerin farklı ortamlarda farklı deneyimlendiği görüşünü vurgulamaktadır. Destinasyonlarda bulunan yapılar, binaların mimari özellikleri, değişen estetik tasarımları, temaları, fiziksel unsurları turistlere birçok açıdan görsel huzur yaşatmaktadır (Oral ve Çelik 2013; Dițoiu ve Căruntu 2014: 302; Agapito vd. 2014: 225 ). Bu gibi görsel çekicilik unsurları turistlerin özellikle de tarihi ve kültürel öneme sahip olan destinasyonlara duygusal açıdan bağlanmalarına neden olabilmektedir (Ujang ve Muslim 2014: 53). Kaçış deneyimi, turistlerin günlük çıkarak, tekrar rutin hayatlarına dönene kadar, onlara farklı ve sıra dışı deneyimler yaşatmayı amaçlamaktadır. Gündelik rutinlerinden çıkan turistlerin bulundukları ortamda kendilerini o ortamın gerektirdiği karaktere bürünmüş hissetmeleri, ortamın büyüsüne kapılarak kendilerini farklı zamanda farklı biri gibi hissetmeleri olağandır. Iso-Ahola (1982) turizmi kaçışa yönelik bir faaliyet olarak kabul etmekte ve kaçış deneyiminin turist deneyimi açısından anahtar bir rol oynadığını ifade etmektedir. Ayrıca, turist güdüleri araştırmaları kaçışı, insanları seyahate yönelten en önemli unsurlardan biri olduğunu öne sürmektedir (Dann 1977: 185; Crompton 1979: 408; Ross ve Iso-Ahola 1991: 226).

\section{YÖNTEM}

Araştırmanın evrenini, 2016 yılının Mart-NisanMayıs aylarında Çanakkale - Gelibolu Yarımadası Tarihi Milli Parkı'nı ziyaret eden, burada en az bir gece konaklama yapan ve böylece bölge hakkında bilgi sahibi olan, burada düzenlenen etkinliklere katılan ve bütünleşik bir deneyim yaşayan yerli ve yabancı turistler oluşturmaktadır. Gelibolu Yarımadası Tarihi Milli Parkı, Türkler, Yeni Zelandalılar ve Avustralyalılar açısından oldukça önemli ve anlamlı bir savaş alanıdır, çünkü 1915 Çanakkale deniz ve kara savaşları bu topraklarda gerçekleşmiştir. Dünya tarihinin en kanlı ve zorlu savaşlarından birinin bu cephede gerçekleştiği bilinmektedir. Bu yüzden tarihi yarımada her yıl binlerce yerli ve yabancı turist tarafından ziyaret edilmektedir. Gelibolu Yarımadası Tarihi Milli Parkı'nı ziyaret edenlerin sayısını belirten herhangi bir sistem bulunmamaktadır. Yerli turistler destinasyona, kendi araçları ile ya da son yıllarda belediyelerin ücretsiz olarak düzenlediği Çanakkale turu kapsamında, otobüsler ile gelmektedirler. Yabancı turistlerin büyük çoğunluğu ise tur operatörleri ya da seyahat acentalar1 vasitası ile destinasyonu ziyaret etmektedir. Yıl içerisinde Gelibolu Yarımadası Tarihi Milli Parkı'nı ziyaret eden turist sayıları ancak tahmin edilebilmektedir. Türkiye turizm istatistiklerinde milliyetlerine göre Türkiye'yi ziyaret eden yabancı turist sayılarına baktığımızda, Avustralya ve Yeni Zelanda'dan, 2018 yılında, toplam 2353 turistin geldiği görülmektedir. Son yıllarda, dünyanın çeşitli ülkelerinden de yabancı turistlerin Gelibolu Yarımadası Tarihi Milli Parkı'nı ziyaret

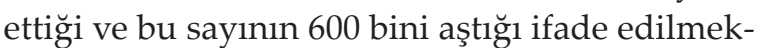
tedir (Birdir, Dalgıç, Güler ve Kayaalp 2015:16). 
Araştırmanın örneklemini 409 yerli turist ve 243 yabanc1 turist olmak üzere toplam $652 \mathrm{ka}$ tılımcı oluşturmaktadır. Araştırma üç aylık bir süreyi kapsamaktadır, bu nedenle evren sayısı tam olarak bilinmemektedir. Evrenin tamamına ulaşılamayan durumlarda yüzde 95 güvenilirlik düzeyi için 384 örneklem sayısının yeterli olduğu öne sürülmektedir (Krejcie ve Morgan 1970: 608). Bu nedenle, 652 anket sayısı yeterli bulunmuştur. Araştırma verileri birincil veri toplama araçlarından yüz yüze anket tekniği ile toplanmıştır. Gelibolu Yarımadası Tarihi Milli Parkı'nda gerçekleştirilen araştırmada örneklem, Gelibolu Yarımadası Tarihi Milli Parkı'nı ziyarete gelenlerden, tesadüfi olmayan örnekleme yöntemlerinden kolayda örnekleme yöntemi ile seçilmiştir. Veriler bu yönteme göre elde edilmiştir. Araştırmanın ölçeğinde yer alan değişkenler, farklı kişiler tarafından çeşitli makalelerde kullanılan, orijinali İngilizce olan ölçeklerden oluşmaktadır. Yerli turistlere uygulanan anketler turizm alanında uzman kişiler tarafından bilimsel yöntemler esas alınarak Türkçeye çevrilmiştir. 100 katılımcıya uygulanan pilot çalışmada ifadelerin geçerlilik ve güvenilirlikleri ölçülmüş ve bunun sonucunda ölçeğin kullanılabilir olacağı sonucuna varılmiştır.

Turizm deneyimi ile ilgili yapılan çalışmalar, turizm deneyiminin seyahat öncesi planlama / hazırlık aşaması, seyahat sırasındaki algılamalar ve seyahat sonrası deneyim olmak üzere üç boyutta ele almaktadır. Bu araştırmada deneyim kavraminın, rasyonel ve duygusal deneyim olmak üzere iki farklı yapıda incelenmesinden dolayı, rasyonel deneyim ölçeğinin üç boyutundan ikisi olan seyahat öncesi planlama deneyimi ve destinasyonda yaşanan deneyim ölçekleri kullanilmaktadir.

Deneyim yapıları ölçeği, deneyimi şu dört boyutta incelemektedir; eğlence, öğrenme, kaçış ve estetik. Bu boyutların her biri incelendiğinde, bilişsel bir deneyim olan öğrenme boyutu rasyonel bir boyut olarak rasyonel deneyim ölçeği içinde ele alınmış, diğer üç boyut ise müşterilerin duygusal durumlarının ele alındığı ölçek olarak kullanılmıştır. Araştırmada kullanılan ölçekler ve kaynakları Tablo 1'de görülmektedir.
Tablo 1. Araştırmada Kullanılan Ölçekler ve Kaynakları

\begin{tabular}{|c|c|c|}
\hline & Değişkenler & Kaynak \\
\hline \multirow{6}{*}{$\begin{array}{l}\text { Rasyonel Müşteri } \\
\text { Deneyimi }\end{array}$} & Seyahat Öncesi Hazırlık & (Meng 2006) \\
\hline & Çabaları & \\
\hline & Seyahat Sırasındaki & \\
\hline & Algılamalar & \\
\hline & Öğrenme Deneyimi & (Oh, Fiore ve \\
\hline & & Jeoung 2007) \\
\hline Duygusal Müşteri & Eğlence Deneyimi & \\
\hline \multirow[t]{2}{*}{ Deneyimi } & Kaçış Deneyimi & (Oh, Fiore \\
\hline & Estetik Deneyimi & ve Jeoung 2007) \\
\hline
\end{tabular}

Müşteri deneyimi alanyazınına bağlı olarak geliştirilen hipotezler şu şekildedir:

$H_{1}$ : Yerli ve yabancı turistler arasında rasyonel müşteri deneyimi açısından istatistiksel olarak anlamlı fark vardır

$\mathrm{H}_{2}$ : Yerli ve yabanci turistler arasinda destinasyonda yaşanan deneyim açısından istatistiksel olarak anlamlı fark vardir

$H_{3}$ : Yerli ve yabancı turistler arasında seyahat öncesi hazırlık deneyimi açısından istatistiksel olarak anlamlı fark vardir

$H_{4}$ : Yerli ve yabancı turistler arasında duygusal müşteri deneyimi açısından istatistiksel olarak anlamlı fark vardır

$H_{5}$ : Yerli ve yabancı turistler arasında eğlence deneyimi açısından istatistiksel olarak anlamlı fark vardır

$H_{6}$ : Yerli ve yabancı turistler arasinda estetik deneyimi açısından istatistiksel olarak anlamlı fark vardır

H7: Yerli ve yabancı turistler arasında kaçış deneyimi açısından istatistiksel olarak anlamlı fark vardır

Araştırmada, anket tekniği ile elde edilen veriler SPSS for Windows 22.00 programı kullanılarak analiz edilmekte ve yorumlanmaktadir. Verilerin analizleri sırasında 1'den (Hiç Katılmıyorum) 5’e (Tamamen Katılıyorum) kadar değişen beşli Likert ölçeği kullanılmıştır.

\section{Veri Analizi ve Bulgular}

Araştırmada kullanılan ölçeklerle ilgili doğrulayıcı faktör analizi yapılmış ve Cronbach's Alpha değerleri hesaplanmıştır. İfadelerin normal dağılıp dağılmadığını anlamak amacıyla normallik testi yapılmıştır ve araştırmada kullanılan ölçek- 
lerden elde edilen değişkenler ve bu değişkenleri oluşturan alt boyutların basıklık ve yaygınlık ölçütlerinin normal dağılım için gerekli olan (-1,5$1,5)$ aralığında olduğu görülmüştür. Daha sonra araştırmada kullanılan ölçek tüm boyutlarının yerli ve yabancı turistlerde karşılaştırılması için bağımsız örneklem t-testinden yararlanılmıştır. Bu çalışmada, yerli ve yabancı turistlerin yaşadıkları deneyim, turistlerin demografik özelliklerinden sadece milliyetlerine göre karşılaştırmalı olarak ele alınmaktadır.

Araştırmaya katılan yabancı ziyaretçilerin $123^{\prime}$ ü (yüzde 50,6) erkek ve 120'si (yüzde 49,4) ise kadındır. Bekâr ziyaretçilerin sayısı 142 (yüzde 58,4), evli ziyaretçilerin sayısı ise 101'dir (yüzde 41,6). .Ziyaretçilerden 110'u (yüzde 45,6) 2130 yaşları arasında, 59'u (yüzde 23,6) 51 yaş ve üzerinde, 44'ü (yüzde 18,3) 41-50 yaşları arasında, 25'i (yüzde 10,4) 31-40 yaşları arasında ve 5'i ise (yüzde 2,1) 20 yaş ve altındadır. Araştırmaya katılan yabancı ziyaretçilerin 118'i (yüzde 48,6) lisansüstü mezunu, 69'u (yüzde 28,4) lise, 54'ü (yüzde 22,2) lisans ve ikisi (yüzde 0,8) ilköğretim mezunudur. Yabancı ziyaretçilerden $108^{\prime}$ inin (yüzde 49,1) aylık kişisel gelirinin 8000 doların üzerinde olduğu, 34' ünün (yüzde 15,5) 2001-4000 dolar arasında, 31'inin (yüzde 14,1) 4001-6000 dolar arasında, 28'inin (yüzde 12,7) 2000 doların altında ve 19'unun ise (yüzde 8,6) 6001-8000 dolar arasında olduğu görülmektedir.

Araştırmaya katılan yabancı ziyaretçilerden 76'sının (yüzde 31,4) Gelibolu Yarımadası Tarihi Milli Parkı hakkındaki bilgi kaynaklarının internet olduğu anlaşılmaktadır. Yabancı ziyaretçilerin 121'inin (yüzde 49,8) Gelibolu Yarımadası Tarihi Milli Parkı'nı daha önce hiç ziyaret etmediği ortaya çıkmaktadır. Yabancı ziyaretçilerden Gelibolu Yarımadası Tarihi Milli Parkı'na yapmış oldukları seyahati 87' sinin (yüzde 35,8) üç-altı ay arasında planladığı görülmektedir. Yabancı ziyaretçilerden 176'sı (yüzde 72,4) Gelibolu Yarımadası Tarihi Milli Parkı'na tatil amaçlı gelmiş ve 150'si (yüzde 61,7) Gelibolu Yarımadası Tarihi Milli Parkı'nda beş günden daha az bir süre kalmıştır. Ayrıca yabancı ziyaretçilerin 114'ü (yüzde $46,9)$ seyahatini organize tur ile gerçekleştirmektedir.
Araştırmaya katılan yerli ziyaretçilerin 241'i (yüzde 58,9) erkek ve 168'i (yüzde 41,1) kadındır. Evli ziyaretçilerin sayısı 180 (yüzde 44) ve bekar ziyaretçilerin sayısı ise 228'dir (yüzde 55,7). Araştırmaya katılan ziyaretçilerin 153'ü (yüzde 37,4) 21-30 yaşları arasında, 60'1 (yüzde 14,7) 3140 yaşları arasında, 60'1 (yüzde 14,7) 41-50 yaşları arasında, 42'si (yüzde 10,3) 51 yaş ve üzerinde ve $39^{\prime} u$ da (yüzde 10,3) 20 yaş ve altındadır. Ziyaretçilerin 54'ü (yüzde 13,2) lisansüstü mezunu, 139'u (yüzde 34,0) lise, 143'ü (yüzde 35,0) lisans ve 11 'i (yüzde 2,7) ilköğretim ve 62' si (yüzde $15,1)$ ön lisans mezunudur. Ziyaretçilerin aylık kişisel gelirlerine bakıldığında, 123'ünün (yüzde 30,7) 1500 TL'nin altında, 117'sinin (yüzde 29,2) 1501-2000 TL arasında, 83'ünün (yüzde 20,7), 3001-4500 TL arasında, 38'inin (yüzde 9,5) 45016000 TL arasında ve 39'unun (yüzde 9,7) ise 6001 TL'nin üzerinde olduğu görülmektedir.

Araştırmaya katılan yerli ziyaretçilerden 105'inin (yüzde 25,7) Gelibolu Yarımadası Tarihi Milli Parkı hakkındaki bilgi kaynağı seyahat acentasıdır. Araştırmaya katılanların 143'ünün (yüzde 35,0) Gelibolu Yarımadası Tarihi Milli Parkı'nı daha önce hiç ziyaret etmediği görülmektedir. Yerli ziyaretçilerin 340'1 (yüzde 83,1) Gelibolu Yarımadası Tarihi Milli Parkı'na yapmış olduğu seyahati üç aydan kısa bir süre içerisinde planlamıştır. Yerli ziyaretçilerin 324'ü (yüzde $79,2)$ Gelibolu Yarımadası Tarihi Milli Parkı'na tatil amaçlı gelmiştir ve 378'i (yüzde 92,4) burada beş günden az kalmıştır. Yerli ziyaretçilerin 201'i (yüzde 49,1) seyahatlerini arkadaşları ile gerçekleştirmiştir.

Daha sonrasında yapılan faktör analizinde faktör yükleri 0,50'nin altında kalan sorular ölçek dışında bırakılmıştır. Faktör Analizinde Hazırlık Çabaları beş alt madde ve Seyahat Sırasındaki Algilamalar ise sekiz alt madde ile temsil edilmişlerdir. Toplam on madde ve üç alt boyuttan oluşan Duygusal Müşteri Deneyimi ölçeğinde tüm boyutlar analizde muhafaza edilmiştir. Faktör yükü düşüklüğü nedeniyle analizden çıkarılan herhangi bir alt madde olmadı ̆̆ından faktör analizinde tüm madde ve boyutlar aynen korunmuştur. Araştırmaya ait Doğrulayıcı Faktör Analiz sonuçları ve güvenilirlik katsayıları Tablo 2'de bulunmaktadır. 
Tablo 2. Rasyonel Müşteri Deneyimi Ölçeği Doğrulayıcı Faktör Analizi Tablosu

\begin{tabular}{|c|c|c|c|c|c|}
\hline Boyutlar & ifadeler & $\begin{array}{l}\text { Faktör } \\
\text { Yükleri }\end{array}$ & Öz Değer & $\begin{array}{l}\text { Açılanan } \\
\text { Varyans }\end{array}$ & $\begin{array}{l}\text { Cronbach's } \\
\quad \text { Alfa }\end{array}$ \\
\hline \multirow[t]{5}{*}{$\begin{array}{l}\text { Hazırlık } \\
\text { Çabaları }\end{array}$} & $\begin{array}{l}\text { Seyahatimi planlarken Gelibolu hakkındaki } \\
\text { bilgilere ulaşmam kolay oldu }\end{array}$ & ,830 & 5,243 & \multirow[t]{5}{*}{25,3} & \multirow[t]{5}{*}{,729 } \\
\hline & $\begin{array}{l}\text { Seyahatimi planlarken Gelibolu ile ilgili çok fazla } \\
\text { bilgi bulabildim }\end{array}$ & ,822 & & & \\
\hline & $\begin{array}{l}\text { Seyahatimi planlarken, uzmanlardan (seyahat } \\
\text { acentası, otel çalışanları gibi) yüksek kalitede } \\
\text { hizmet aldım }\end{array}$ & ,527 & & & \\
\hline & $\begin{array}{l}\text { Seyahat hazırlıkları aşamasında hiçbir problem ile } \\
\text { karşılaşmadım (ulaşım, konaklama gibi) }\end{array}$ & ,580 & & & \\
\hline & $\begin{array}{l}\text { Seyahatin fiyatını uygun buldum (ulaşım, } \\
\text { konaklama, etkinlikler gibi) }\end{array}$ & ,724 & & & \\
\hline \multirow{8}{*}{$\begin{array}{l}\text { Seyahat } \\
\text { Sırasındaki } \\
\text { Algılamalar }\end{array}$} & Gelibolu'da konaklama yerleri kalitelidir & ,740 & 3,366 & \multirow[t]{8}{*}{18,4} & \multirow[t]{8}{*}{873} \\
\hline & Gelibolu'da yemekler kalitelidir & ,746 & & & \\
\hline & Gelibolu'da birçok etkinlik bulunmaktadır & ,754 & & & \\
\hline & $\begin{array}{l}\text { Gelibolu'da arasından seçim yapılabilecek kadar } \\
\text { çok çeşitli etkinlik bulunmaktadır }\end{array}$ & ,748 & & & \\
\hline & Fiyatlar genel olarak uygundur & ,587 & & & \\
\hline & Yüksek kalitede hizmet aldım & 7117 & & & \\
\hline & Gelibolu'da çok şey öğrendim & ,718 & & & \\
\hline & $\begin{array}{l}\text { Gelibolu'da öğrendiklerim, beni daha fazla şey } \\
\text { öğrenmeye teşvik etti }\end{array}$ & ,686 & & & \\
\hline
\end{tabular}

Araştırmada kullanılan ölçek tüm boyutlarının yerli ve yabancı ziyaretçilerde karşılaştırılması için bağımsız örneklem $\mathrm{z}$ testinden yararlanılmıştır. Yerli (409 ziyaretçi) ve yabancı (243 ziyaretçi) grupların toplamı (652 ziyaretçi) alındığından fark testlerinde bu boyutların iki grup arasında istatistiksel farklılı̆̆a yol açıp açmadığı incelenmiştir. Araştırmada kullanılan ölçeklerin bütün boyutlarının yerli ve yabancı ziyaretçilerde karşılaştırılması Tablo 4'te görülmektedir.
Araştırmada kullanılan iki adet ölçekte yer alan ana faktörler ve her ölçeğe ait alt boyutlar yerli ve yabancı turistler için bağımsız iki örnek z testi ile karşılaştırılmıştır.

Rasyonel müşteri deneyimi ve alt boyutları olan hazırlık çabaları ve seyahat sırasındaki algilamalar boyutlarında test olasılık değeri $p>0,05$ olduğundan istatistiksel olarak anlamlı farklılık tespit edilememiştir. Yerli ve yabancı turistle- 
Tablo 3. Duygusal Müşteri Deneyimi Ölçeği Doğrulayıcı Faktör Analizi Tablosu

\begin{tabular}{|c|c|c|c|c|c|}
\hline Boyutlar & ifadeler & $\begin{array}{l}\text { Faktör } \\
\text { Yükleri }\end{array}$ & Öz Değer & $\begin{array}{l}\text { Açıklanan } \\
\text { Varyans }\end{array}$ & Cronbach's Alfa \\
\hline \multirow{4}{*}{$\begin{array}{l}\text { Estetik } \\
\text { Deneyimi }\end{array}$} & Gelibolu'da gerçek bir ahenk/uyum hissettim & ,835 & 2,502 & \multirow[t]{4}{*}{20,4} & \multirow[t]{4}{*}{, 846} \\
\hline & Gelibolu'da olmak çok zevkliydi & 773 & & & \\
\hline & Gelibolu çok etkileyici bir yer & 678 & & & \\
\hline & $\begin{array}{l}\text { Buranın yerleşimi duyularıma huzur verdi } \\
\text { (koklama, görme, tatma, duyma, dokunma) }\end{array}$ & ,864 & & & \\
\hline \multirow{3}{*}{$\begin{array}{l}\text { Eğlence } \\
\text { Deneyimi }\end{array}$} & Gelibolu'da güzel vakit geçirdim & ,721 & 2,052 & \multirow[t]{3}{*}{26,7} & \multirow[t]{3}{*}{, 857} \\
\hline & $\begin{array}{l}\text { Gelibolu'daki etkinlikleri izlerken hoşça vakit } \\
\text { geçirdim }\end{array}$ & ,897 & & & \\
\hline & Gelibolu'daki etkinlikleri izlemek güzeldi & ,853 & & & \\
\hline \multirow[t]{3}{*}{$\begin{array}{l}\text { Kaçış } \\
\text { Deneyimi }\end{array}$} & $\begin{array}{l}\text { Gelibolu'da kendimi farklı bir karaktermişim } \\
\text { gibi hissettim }\end{array}$ & ,762 & 1,942 & \multirow[t]{3}{*}{35,6} & \multirow[t]{3}{*}{, 841} \\
\hline & $\begin{array}{l}\text { Gelibolu'da kendimi başka bir yer ve zamanda } \\
\text { yaşıyormuş gibi hissettim }\end{array}$ & ,856 & & & \\
\hline & $\begin{array}{l}\text { Gelibolu'da gerçek yaşamımdan tamamen } \\
\text { uzaklaşmış hissettim }\end{array}$ & 793 & & & \\
\hline
\end{tabular}

rin görüşleri arasında farklılık yoktur. Diğer bir ana faktör olan duygusal müşteri deneyimi ve alt boyutları olasılık değerleri $(p<0,05)$ olduğun- dan yerli ve yabancı turistlerin bu ifadelere kat1lım düzeyleri arasında istatistiksel olarak anlamlı farklılık tespit edilmiştir.

Tablo 4. Araştırmada Kullanılan Ölçek Alt Boyutlarının Yerli ve Yabancı Ziyaretçiler İçin Yapılan z-testi Analizi

\begin{tabular}{|c|c|c|c|c|c|c|c|}
\hline & Uyruk & $N$ & $A O$ & Ss. & $T$ & $d f$ & $P$ \\
\hline \multirow[t]{2}{*}{ Hazırlık çabaları } & Yerli & 409 & 3,9479 & ,65627 & $-1,245$ & 650 & ,214 \\
\hline & Yabancı & 243 & 4,0244 & ,81479 & & & \\
\hline \multirow[t]{2}{*}{ Seyahat sırasındaki algılamalar } & Yerli & 409 & 4,0947 & ,65183 & 1,822 & 650 & ,069 \\
\hline & Yabancı & 243 & 3,9878 & ,76366 & & & \\
\hline \multirow[t]{2}{*}{ Rasyonel Müşteri Deneyimi } & Yerli & 409 & 4,0213 & ,53762 & ,296 & 650 & ,767 \\
\hline & Yabancı & 243 & 4,0061 & ,68214 & & & \\
\hline \multirow[t]{2}{*}{ Estetik } & Yerli & 409 & 3,8683 & ,64053 & 3,420 & 650 &, $001^{* *}$ \\
\hline & Yabancı & 243 & 3,6858 & ,66950 & & & \\
\hline \multirow[t]{2}{*}{ Eğlence } & Yerli & 409 & 4,2634 & ,71768 & 3,946 & 650 &, $000 * *$ \\
\hline & Yabancı & 243 & 3,9963 & ,89832 & & & \\
\hline \multirow[t]{2}{*}{ Kaçış } & Yerli & 409 & 4,6111 & 79253 & 7,830 & 650 &, $000^{* *}$ \\
\hline & Yabancı & 243 & 3,0513 & ,93203 & & & \\
\hline \multirow[t]{2}{*}{ Duygusal Müşteri Deneyimi } & Yerli & 409 & 4,2476 & ,57722 & 6,431 & 650 &, $000 * *$ \\
\hline & Yabancı & 243 & 3,9112 & ,68340 & & & \\
\hline
\end{tabular}

${ }^{* *} p<0,01{ }^{*} p<0,05$ 
Duygusal müşteri deneyimi ana boyutunda yabanci turistlerin ortalamasi $(4,24)$, yerli turist grubunun ortalamasından $(3,91)$ yüksek bulunmuştur. Alt boyutlarda ise bulgular şu şekildedir:

- Estetik alt boyutunda yerli turistlerin ortalaması $(3,86)$, yabanc1 turist grubunun ortalamasindan $(3,68)$ yüksek bulunmuştur.

- Eğlence alt boyutunda yerli turistlerin ortalamasi $(4,26)$, yabanc1 turist grubunun ortalamasindan $(3,99)$ yüksek bulunmuştur.

- Kaçış alt boyutunda yerli turistlerin ortalamaS1 $(4,61)$, yabanc1 turist grubunun ortalamasından $(3,05)$ yüksek bulunmuştur.

\section{SONUÇ}

Çalışmanın analiz sonuçlarına bakıldığında, Gelibolu Yarımadası Tarihi Milli Parkı'nı ziyaret eden yerli ve yabancı turistlerin yaşadıkları rasyonel deneyim ana boyutunda herhangi bir farklılık bulunmadığ 1 görülmektedir. Yerli ve yabancı turistler, destinasyona gelmeden önceki hazırlık çabaları esnasında ve seyahatleri sırasında yaşadıkları rasyonel deneyimi benzer şekilde algılamışlardır. Ayrıca, yaşadıkları bu rasyonel deneyimden de memnun kaldıkları görülmektedir. Diğer taraftan, yerli ve yabancı turistlerin yaşadıkları duygusal deneyim arasında farklılıklar bulunmaktadır. Duygusal müşteri deneyimi ana boyutunda yabanc1 turistlerin ortalaması, yerli turistlerin ortalamasından düşüktür. Yerli turistlerin, destinasyonda yabancı turistlere göre daha olumlu bir duygusal deneyim yaşadıkları ortaya koyulmaktadır. Duygusal deneyimin alt boyutlarına baktığımızda eğlence, kaçış ve estetik alt boyutlarında yabancı turistlerin ortalamasının, yerli turistlerin ortalamasından düşük olduğu görülmektedir. Buna göre, yabancı turistler destinasyonda olmaktan ve destinasyonda gerçekleştirilen etkinliklerden yerli turistlere göre daha az keyif almaktadır. Yerli turistler yabancı turistlere göre, kendilerini gerçek yaşamdan daha çok uzaklaşmış, başka bir zaman ve yerde yaşıyormuş gibi daha fazla hissetmekte ve kendilerini destinasyonun büyüsüne daha fazla kaptırarak başka bir karaktere bürünmüş hissetmektedirler. Ayrıca, yerli turistlerin yabancı turistlere göre,
Gelibolu Yarımadası Tarihi Milli Parkı'nda daha fazla bir ahenk hissettikleri, burayı daha çok etkileyici buldukları, buranın yerleşiminin duyularına daha fazla huzur verdiği ve burada olmaktan daha fazla zevk aldıkları sonucuna ulaşılmaktadır.

Bu çalışmanın, daha önce yapılmış olan bazı çalışmalar ile uyum gösterdiği ve benzer sonuçlara ulaşıldığı görülmektedir. Hirschman ve Holbrook tarafından 1982 yılında yapılan çalışmada tüketim deneyiminin genellikle fanteziler, duygular ve eğlence ile gerçekleştiği sonucuna ulaşılmıştır (Hirschman ve Holbrook 1982). Bu çalışmada da aynı şekilde rasyonel ve duygusal deneyimin bütününü oluşturan müşteri deneyiminde hem yerli hem de yabancı ziyaretçilerin yaşadıkları duygusal deneyimin müşteri deneyimini rasyonel deneyimden daha fazla oranda etkilediği benzer şekilde bulunmuştur.

Diğer taraftan Benkenstein, Yavaş ve Forberger'in (2008) Almanya'da bulunan Rostock Hayvanat Bahçesini ziyarete gelen 350 turist üzerinde yaptıkları çalışmada, turistlerin rasyonel ve duygusal değerlendirmelerinin müşteri memnuniyeti ile nasıl bir ilişkisi olduğunu anlamak amacıyla bir model geliştirilerek test edilmiştir. Çalışmanın sonunda, turistlerin boş zaman hizmetlerinden elde edilen tüketici memnuniyetinin, duygusal değerlendirmelerin daha hâkim olduğu, rasyonel (hizmet alanında bulunan somut unsurlar) ve duygusal (soyut unsurlar) değerlendirmelerin bir fonksiyonu olduğu sonucu ortaya çıkmaktadır. Çalışmada ayrıca, turistlerin duygusal ve rasyonel değerlendirmeleri arasında da bir ilişki olduğu sonucu ortaya koyulmaktadır. Yapılan çalışmanın da aynı şekilde yerli ve yabancı turistlerden oluşan her iki grup üzerinde de daha çok duygusal deneyimin hâkim olduğu ortaya çıkmıştır. Ayrıca bu çalışma da rasyonel ve duygusal deneyim arasında güçlü bir ilişki olduğunu ortaya koymaktadır.

\section{ÖNERILER}

Rekabetin her geçen gün daha da arttığ günümüz turizm pazarlarında, başarılı ve sürdürülebilir bir destinasyon planlaması, yönetimi ve pazarlaması açısından turistlerin destinasyona gelmeden önce ve destinasyonları ziyaret sırasın- 
da yaşadıkları rasyonel ve duygusal deneyimler önemlidir. Bu nedenle, destinasyon pazarlamacı ve planlayıcılarının, Gelibolu Yarımadası Milli Parkı'nı ziyarete gelen turistlerin kolayca ulaşabileceği, güvenilir, güncel ve bol miktarda bilgi sağlamaya odaklanmaları gerekmektedir. Ayrıca turizm işletmelerinin de seyahatlerini planlama aşamasında olan turistlere her konuda yardım etmeleri gerekmektedir. Bu tür hizmetler destinasyonların potansiyel turistlere tanitılması ve pazarlanması açısından büyük önem taşımaktadır. Ayrıca, turistlere yönelik çeşitli öğretici, eğlendirici ve onların hoşça vakit geçirmelerini sağlayacak etkinlikler düzenlenmeli ve turistlerin bu etkinlikler ve faaliyetler ile destinasyonda farklı bir yerde ve zamanda yaşıyormuş gibi ve gerçek yaşamlarından tamamen uzaklaşmaları sağlanmalıdır. İşletmelerin ve destinasyon yöneticilerinin destinasyonu ziyaret eden turistlere duygusal bir deneyim yaşatmalarının, turistlerin duygularını harekete geçirmeleri, onların duyularına ve duygularına hitap edecek farklılıklar yaratmaları açsından oldukça önemlidir.

Müşteri deneyimi konusunda yapılan çalışmalar oldukça sınırlıdır. Müşteri deneyimini etkileyen birçok farklı unsur bulunmaktadır. Bunlardan bazıları, kişilerin karakteri, güdüleri ya da hissettikleri farklı duygular gibi. Bu unsurları da modele dahil ederek ya da farklı bir model oluşturularak farklı bir çalışma yapılabilir. Bu çalışma belirli bir dönemi kapsamaktadır. Böyle bir çalışma destinasyonu ziyaret eden turistlere her yıl yapılabilir. Bu durum yıllara göre karşılaştırma yapma olanağ da bulunan otel, turizm acentaları ya da yiyecek içecek işletmelerinin müşterilerine yaşattığı deneyimler üzerine odaklanmak da verimli bir çalışma sağlayabilecektir. Bu araştırmada kullanılan yöntemden farklı olarak görüşme, odak grup oluşturma gibi yöntemler kullanılarak bu çalışmanın sonuçları ile karşılaştırılabilir.

\section{KAYNAKÇA}

Addis, Michela ve Morris B. Holbrook (2001). On the Conceptual Link between Mass Customisation and Experiential Consumption: An Explosion of Subjectivity, Journal of Consumer Behaviour, 1(1): 50-66.
Agapito, D., Valle, P. ve Mendes, J. (2014). The Sensory Dimension of Tourist Experiences: Capturing Meaningful Sensory-Informed Themes in Southwest Portugal, Tourism Management, 42: 224-237.

Becken, S. ve Wilson, J. (2007). Trip Planning and Decision Making of Self-Drive Tourists- Quasi-Experimental Approach, Journal of Travel \& Tourism Marketing, 20(34): 47-62.

Berry, Leonard L., Carbone, Lewis P. ve Haeckel, Stephan H. (2002). Managing the Total Customer Experience, Sloan Management Review, 43(3): 85-90.

Bieger, T. ve Laesser, C. (2004). Information Sources for Travel Decisions: Toward a Source Process Model, Journal of Travel Research, 42(4): 357-371.

Birdir, K., Dalgıç, A., Güler, O. ve Kayaalp, Y. (2015). Hüzün Turizmi: Gelibolu Yarımadası Tarihi Milli Parkını Ziyaret Eden Yabanc1, Journal of Tourism and Gastronomy Studies, 3(4): 12- 23.

Bitner, M. J. (1992). Servicescapes: The Impact of Physical Surroundings on Customers and Employees, The Journal of Marketing, 56(2): 57-71.

Carbone, L. P. ve Haeckel, S. H. (1994). Engineering Customer Experiences, Marketing Management, 3(3): 8-19.

Crompton, J. L. (1979). Motivations for Pleasure Vacation, $A n$ nals of tourism research, 6(4): 408-424.

Çetin G. (2012). Konaklama İşletmelerinde Müşteri Deneyiminin Sadakat ve Tavsiye Davranıșına Etkisi. (Basılmamış Doktora Tezi). İstanbul: İstanbul Üniversitesi Sosyal Bilimler Enstitüsü, İşletme Ana Bilim Dalı

Dann, G. M. S. (1977). Anomie, Ego-Enhancement and Tourism, Annals of tourism research, 4(4): 184-194.

Diţoiu, M.-C. ve Coruntu, A.-L. (2014). Sensory Experiences Regarding Five-Dimensional Brand Destination, Procedia-Social and Behavioral Sciences, 109: 301-306.

Fyall, A. ve Leask, A. (2006). Destination Marketing: Future Issues-Strategic Challenges, Tourism and Hospitality Research, 7(1): 50-63.

Gretzel, U., Fesenmaier, D. R., Formica, S. ve O'Leary, J. T. (2006). Searching for the Future: Challenges Faced by Destination Marketing Organizations, Journal of Travel Research, 45(2):116-126.

Gronau, W. (2017). Encouraging Behavioural Change Towards Sustainable Tourism: A German Approach to Free Public Transport for Tourists, Journal of Sustainable Tourism, 25(2): 265-275.

Hirschman, C. E. ve Holbrook, B. M. (1982). Hedonic Consumption: Emerging Concepts, Methods and Propositions, Journal of Marketing, 46 (3): 92-101.

Holbrook, B. Moris ve Hirschman, C. Elizabeth (1982). The Experiential Aspects of Consumption: Consumer Fantasies, Feelings, and Fun, Journal of Consumer Research, 9(2): 132-140.

Hosany, S. ve Gilbert, D. (2010). Measuring Tourists' Emotional Experiences Toward Hedonic Holiday Destinations, Journal of Travel Research, 49(4): 513-526.

Hosany, S. ve Witham, M. (2010). Dimensions of Cruisers' Experiences, Satisfaction and Intention to Recommend, Journal of Travel Research, 49(3): 351-364. 
Iso-Ahola, S. E. (1982). Toward a Social Psychological Theory of Tourism Motivation: A Rejoinder, Annals of Tourism Research, 9(2): 256-262.

Kim, K., Hallab, Z. ve Kim, J. N. (2012). The Moderating Effect of Travel Experience in a Destination on the Relationship Between the Destination Image and the Intention to Revisit, Journal of Hospitality Marketing \& Management, 21(5): 486-505.

Kim, W. G. ve Moon, Y. J. (2009). Customers' Cognitive, Emotional, and Actionable Response to the Servicescape: A Test of the Moderating Effect of the Restaurant Type, International Journal of Hospitality Management, 28(1): 144-156.

Kozak, M. ve Rimmington, M. (2000). Tourist Satisfaction With Mallorca, Spain, as an Off-Season Holiday Destination, Journal of Travel Research, 38(3): 260-269.

Krejcie, R. V. ve Morgan, D. W. (1970). Determining Sample Size For Research Activities, Educational and Psychological Measurement, 30(3): 607-610.

Lee, S., Jeon, S. ve Kim, D. (2011). The Impact of Tour Quality and Tourist Satisfaction on Tourist Loyalty: The Case of Chinese Tourists in Korea, Tourism Management, 32(5): 1115-1124.

Loi, K.I. (2008). Gaming and Entertainment Tourist Destinations: A World of Similarities and Differences, Tourism Recreation Research, 33(2): 165-183.

Oral, S. ve Çelik, A. (2013). Türkiye'yi Ziyaret Eden Turistlerin Estetik Deneyimleri Üzerine Bir Araştırma, İşletme Araştırmaları Dergisi, 5(4): 170-190.

Oh, H., Fiore, A. M. ve Jeoung, M. (2007). Measuring Experience Economy Concepts: Tourism Applications, Journal of Travel Research, 46(2):119-132.

Pine, B. J. ve Gilmore, J. H. (1999). The Experience Economy: Work is Theatre and Every Business a Stage, Cambridge, MA: Harvard Business School Press.
Ritchie, J. R. Brent ve Hudson, Simon (2009). Understanding and Meeting the Challenges of Consumer/Tourist Experience Research, International Journal of Tourism Research, 11:111-126.

Ross, E. L. D. ve Iso-Ahola, S. E. (1991). Sightseeing Tourists' Motivation and Satisfaction, Annals of Tourism Research, 18(2): 226-237.

Schmitt, B. H. (1999). Experiential Marketing, Journal of Marketing Management, 15(1-3): 53-67.

Sirakaya, E. ve Woodside, A. G. (2005). Building and Testing Theories of Decision Making by Travellers, Tourism Management, 26(6): 815-832.

Tian-Cole, S. ve Cromption, J. (2003). A Conceptualization of the Relationships between Service Quality and Visitor Satisfaction, and Their Links to Destination Selection, Leisure Studies, 22(1): 65-80.

Tung, V. W. S. ve Ritchie, J. R. B. (2011). Exploring the Essence of Memorable Tourism Experiences, Annals of Tourism Research, 38(4):1367-1386.

Ujang, N. ve Muslim, Z. (2014). Walkability and Attachment to Tourism Places in the City of Kuala Lumpur, Malaysia, Athens Journal of Tourism, 1(1): 53-66.

Walls, A., Okumuş F., Wang Y. ve Kwun, D. J. (2011). Understanding the Consumer Experience: An Exploratory Study of Luxury Hotels, Journal of Hospitality Marketing and Management, 20(2): 166-197.

Williams, A. (2006). Tourism and Hospitality Marketing: Fantasy, Feeling and Fun, International Journal of Contemporary Hospitality Management, 18(6): 482-495.

Yoon, Y. ve Uysal, M. (2005). An Examination of the Effects of Motivation and Satisfaction on Destination Loyalty: A Structural Model, Tourism Management, 26(1): 45-56.

Yüksel, A. ve Yüksel, F. (2001). The Expectancy-Disconfirmation Paradigm: A Critique, Journal of Hospitality \& Tourism Research, 25(2): 107-131.

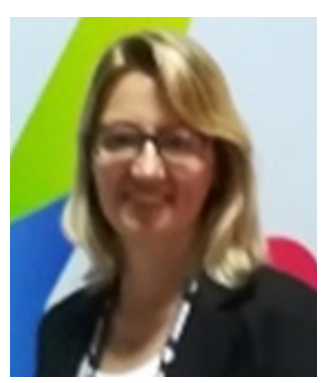

Neslihan CAVLAK

Bilkent Üniversitesi Turizm ve Otel İşletmeciliği Bölümü'nden mezun oldu (1999). Yüksek lisans derecesini Kadir Has Üniversitesi İşletme Dalı’ndan (2008), doktora derecesini de Bolu Abant İzzet Baysal Üniversitesi'nden İşletme Dalı'ndan aldı (2017). İstanbul Aydın Üniversitesi Turizm ve Otel İşletmeciliği Bölümü’nde çalışmaya başladı (2004). Sonrasında ise sırasıyla, Maltepe Üniversitesi, Düzce Üniversiteleri’nde görev aldı. Halen Tekirdağ Namık Kemal Üniversitesi Malkara Meslek Yüksekokulu'nda görev yapmaktadır. Temel çalışma alanları, turizm ve otel işletmeciliği, turizm pazarlama$\mathrm{sı}$, turist davranışı, destinasyon pazarlamasıdır.

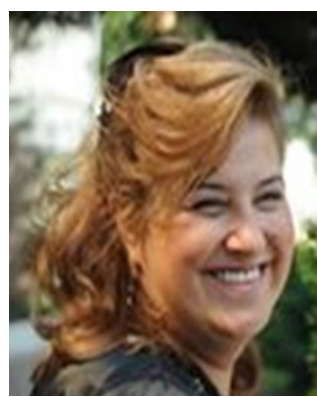

\section{Ruziye COP}

Gazi Üniversitesi İktisadi ve İdari Bilimler Fakültesi İşletme Bölümü’nden mezun oldu (1984). Yüksek lisans derecesini Gazi Üniversitesi İktisadi ve İdari Bilimler Fakültesi İşletme Dalı'ndan (1988), doktora derecesini de İstanbul Üniversitesi'nden İşletme Dalı́ndan aldı (1994). Abant İzzet Baysal Üniversitesi'nde çalıșmaya başladı (1992). Sonrasında ise Bülent Ecevit Üniversitesi'nde çalıştı. Doçentlik unvanını Pazarlama alanından aldı (2011). Profesörlüğe Bolu Abant İzzet Baysal Üniversitesi'nde yükseltildi. Halen Bolu Abant İzzet Baysal Üniversitesi İktisadi ve İdari Bilimler Fakültesi İşletme Bölümü'nde görev yapmaktadır. Temel çalışma alanları, pazarlama, ürün ve marka yönetimi, satış yönetimidir. 